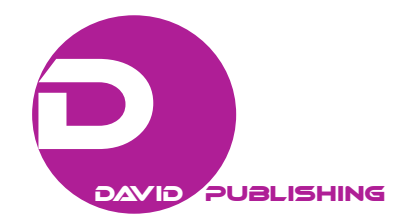

\title{
Business Education in the E-World: Challenges and the Way Forward
}

\author{
Jacinta Ifeoma Obidile \\ Nnamdi Azikiwe University, Awka, Nigeria \\ Josephat N. Onyeagba \\ Nwafor Orizu College of Education, Nsugbe, Nigeria
}

\begin{abstract}
With the rapid development and utilization of information and communication technology (ICT) facilities in the teaching and learning processes especially in the teaching and learning of business education, it becomes important to ascertain the state of business education in the electronic world (e-world), benefits of ICT integration in business education and challenges facing business education in the e-world and the way out.

Keywords: business education, e-world, ICT/business education challenges, ICT facilities, ICT integration, ICT utilization
\end{abstract}

\section{Introduction}

Business education is an aspect of vocational and technical education. It is a specialized programme of instruction designed to provide individuals with knowledge, skill, and attitude for occupational work and advancement. According to Gana and Abdulrahman (2017), business education is a wide field of discipline, which prepares individual with relevant and saleable skills for effective self and societal development. Courses offer in business education are developed to expose students to core areas like accounting, commerce and cooperative/distributive education and marketing, secretarial studies, agriculture, and home economics. According to Okwuanaso and Nwazor (2000), business education involves teaching students the fundamentals, theories, and processes of business and its related activities. According to Akinola (2006), the following are the objectives of business education:

1. To prepare students for employment after graduation;

2. To meet the manpower needs of the society;

3. To give students background training that would contribute to rapid advancement on the job;

4. To give training and impart the necessary skills leading to the production of craftsmen, technicians, and other skilled personnel who would be self reliant;

5. To provide knowledge and skills necessary for industrial, commercial, and economic development.

Business education is offered at different levels of the education system, which include basic, post basic, and tertiary levels. At pre-tertiary level, it is often called business studies and usually combines elements of accounting, finance, marketing, organizational studies, human resource management, and economics. In this era

Jacinta Ifeoma Obidile, Ph.D., lecturer, Department of Technology and Vocational Education, Nnamdi Azikiwe University. Josephat N. Onyeagba, MBA, principal lecturer, Department of Business Education, Nwafor Orizu College of Education. 
of globalization, where the free flow of information for instructional purposes is made possible through the use of electronic components, such as the Internet, computer, and satellite, there is need for business educators to be adequately equipped to tackle the challenges posed by the information and communication technology (ICT) facilities’ utilization.

ICT facilities, according to Egoeze, Ibrahim-Akman, and Colomo-Palacios (2014), are the products of merged technologies of computer, computer networks, and communication. They are facilities arising from technological progress in computer science, electronic, and telecommunications. ICT facilities mostly used in education, according to Anunobi and Edoka (2010), include disks, flash memories, multimedia projectors, interactive electronic boards, personal computers, cable, satellite, wireless links, Personal Area Network (PAN), Campus Area Network (CAN), intranets, extranets, and Internet. With the development and utilization of ICT facilities in education sector, several changes are observed in the way education institutions operate and communicate. This in turn has impact on educational and training needs of business educators and their students.

\section{Business Education Programme in the Electronic World (E-World)}

Utilization of ICT facilities in the teaching and learning of business education courses has the potential to improve the ways of instruction, where and how learning occurs and the roles of students and educators in the instructional process (United Nations Educational Scientific and Cultural Organization [UNESCO], 2002a). It fosters global communication and helps to accomplish tasks faster, more precisely and reliably. It fosters technological literacy and facilitates teaching and learning processes. According to Richmond (2002), instructional use of computers has three dimensions, which include:

(a) learning about computers and the Internet, in which technological literacy is the end goal;

(b) learning with computers and the Internet, in which the technology facilitates learning across the curriculum;

(c) learning through computers and the Internet, integrating technological skills development with curriculum applications.

In the same vein, Okoro and Ekpe (2016), categorized ICT utilization in education into two broad areas, namely: ICT in education and ICT for education. According to the authors, ICT in education serves as the change agent in the teaching and learning processes, while ICT for education serves as the instrument for improving the quality of education. This implies that ICT facilities could change the teaching and learning processes as they serve as instruments in the teaching and learning processes.

However, for the integration of ICT facilities in the teaching and learning of business education courses to be maximally implemented, consideration must be given to changes in the curriculum, instructional processes, assessment and teacher education. For effective delivery of an ICT-based curriculum in business education, teacher education and support services are necessary. Since business educators are expected to impart the necessary ICT knowledge and skills to their students to enable the students know how to use the ICT facilities in diverse applications in learning, business, industry and commerce, they are expected to possess the adequate competencies necessary for utilization of ICT facilities in the teaching and learning processes. 


\section{Benefits of Integrating ICT Facilities in the Teaching and Learning of Business Education in the E-World}

Integrating ICT facilities in the teaching and learning of business education in the e-word could:

\section{Enhance Accessibility of Business Education}

Through the use of ICT facilities in education, distance learning is made possible and this helps to enhance the accessibility of education programmes including business education programme to individuals who are constrained from attending traditional universities.

\section{Serve as Aids to Learning}

ICT facilities bring the Internet, the Web, and computer-assisted learning to the teaching and learning of business education courses and could make the courses easier, interesting, accommodating and participatory. Also, they could improve the teaching and learning standard by encouraging learning through ongoing discussion, directed instruction, self-learning, critical thinking, data seeking and analysis (Moseley et al., 1999; Yuen, Law, \& Wong, 2003). They also help in quick storage and retrieval of data in the teaching and learning process (Ali, Haolader, \& Muhammad, 2013). Furthermore, they create important abilities in the underprivileged groups (Sharma, 2003).

\section{Problems Facing the Teaching and Learning of Business Education in the E-World}

Looking at the developing nations, such as Nigeria, there are several challenges that impede the integration of ICT facilities in the teaching and learning processes especially in the teaching and learning of business education. They include but not limited to economic barrier, political barrier, technological barrier, personal factors, ICT training needs, and curriculum re-evaluation.

\section{Economic Barrier}

This is the inability to develop, manage, utilize and sustain ICT facilities in the teaching and learning processes due to inadequate funding. Inadequate funding has made the purchase and maintenance of ICT facilities in education sector difficult (Rumanyika \& Galan, 2015). Internet services are quite expensive for online learning. Expensive hardware and software facilities as well as high costs of communication services restrict access to ICT usage in the teaching and learning processes. Most schools in Nigeria do not have adequate fund to purchase the necessary ICT facilities needed in the teaching and learning of business education courses.

\section{Political Barrier}

This is the inability to utilize the ICT facilities in the teaching and learning processes due to the attitude of the political administrators towards ICT implementation in education sector. Nigerian government usually apportions less than $10 \%$ of the nation's income to education sector which is far less the approved percentage given by the United Nations. This makes the improvement in education sector most times difficult. ICT facilities are usually cost intensive and could not be adequately purchased without adequate funding and investment in education sector. It is therefore important that the education favorable policies in Nigeria should be judiciously implemented, so as to enhance the production of competent and competitive graduates. The nation's leaders should not play politics with the education of their citizens. They should provide adequate funding (as approved by the United Nations), resources, facilities, tools and equipment to the education sector. 
They should ensure minimal tax rates on the ICT that are being utilized in the teaching and learning processes, so as to reduce their high cost. According to Minishi-Majanja (2007), Rumanyika and Galan's (2015) computers and related items are often treated as luxury items and heavy government taxes are imposed on them which increase the cost of such equipment.

\section{Technological Barrier}

This is the inability to utilize the ICT facilities in the teaching and learning processes due to problems arising from technology breakthrough which include rapid technological advancement, inadequate modern technological facilities, unavailability of the spare parts and inadequate technical support. It is important that technological advancement should follow a gradual process especially in a developing nation like Nigeria where the utilization of ICT facilities in education sector is yet to be fully implemented. Adequate modern technological facilities should always be made available, technical support should be put in place and spare parts made available to facilitate the utilization of ICT facilities. ICT spare parts should be encouraged to be produced within the country as Nigeria has the potentials to produce them only that other necessary resources like funding should be made available.

\section{Personal Factors}

Certain competencies are required to be developed by the business educators and their students for ICT facilities to be optimally utilized in the teaching and learning of business education courses. Simply providing ICT facilities in the teaching and learning of business education is not enough. It should be backed up with adequate provision of requisite competencies needed in the utilization of ICT facilities in the teaching and learning processes. According to Yusuf (2005) and Omariba (2012), many teachers cannot teach with ICT facilities, because they are not competent in basic computer operation and in the use of some software applications. Obidile (2013) stated that the benefits of ICT facilities cannot be maximally utilized in education if teachers find it difficult to use them due to their inability to carry out their roles effectively. Business educators should therefore make personal effort to acquaint themselves with the necessary competencies needed for ICT integration in the teaching and learning processes.

\section{ICT Training Needs}

With the advent of ICT facilities in the teaching and learning processes, it becomes important that business educators should be re-tooled for easy utilization of ICT facilities in the teaching and learning processes. Adequate technological literacy should be provided to both the pre-service and in-service business educators to enable them impart the necessary ICT knowledge and skills to their students.

\section{Curriculum Re-Evaluation}

Re-evaluation of the business education curriculum due to ICT integration is very necessary. ICT in education creates problems of how to deal with potential changes in curriculum, instructional processes and assessment. Providing ICT based curriculum would help both the business educators and their students to be knowledgeable with the requirements of ICT application and help them to be conversant with the terms and practices embedded in the e-world. Competency-oriented approach should be adopted in business education curriculum design, so as to enhance the employability of their graduates and prepare them for work in the e-world. Business education curriculum should be seriously adjusted to respond to labour market challenges.

Other constraints of ICT integration in the teaching and learning processes as suggested by other scholars 
include irregular or unavailability of electricity supply, insufficient ICT equipment, inappropriate software and high cost of software licenses (Anderson, 1997); students' attitude, inappropriate teaching methodology and capacity building (Mikre, 2011); teachers' attitudes, leadership support and pressure to use technology (Ali, Haolader, \& Muhammad, 2013); and limited amount of resources to introduce and replicate technology to help train graduates (Atepor, 2018).

\section{The Way Forward}

Some strategies could be used to enhance the integration of ICT facilities in the teaching and learning of business education in order to enhance the production of competitive graduates. They include:

\section{Establishment of Free ICT Learning Resource Centres}

Free ICT learning resource centres should be established in schools. The centres would offer training on ICT integration in education for business educators and their students. This is necessary as application of ICT facilities in the teaching and learning should be practice oriented, dynamic and activity-based, so as arouse students' interest.

\section{Establishment of Business Education Network Trust Fund (BENTF)}

Stakeholders in business education should provide support to the programme through the provision of funds to establish Business Education Network Trust Fund (BENTF). This fund would be used solely for the purchase of ICT facilities, tools and equipment needed in the teaching and learning of business education courses.

\section{Subsidy on Software License}

Federal government should subsidize software license in order to enable soft ware providers to produce affordable software that could be used in the teaching and learning processes.

\section{Production of Indigenous ICT Facilities}

Effort should be made by the government to establish ICT production companies in Nigeria or attract ICT production companies to Nigeria. This would help the nation to have the ICT facilities that would be adaptable to their environment especially in the teaching and learning situations. It could also enhance the durability of the facilities. Furthermore, it would also ensure that competent workforce are trained to handle the production, repairs and maintenance of ICT facilities for teaching and learning purposes.

\section{Integrating ICT Facilities in the Teaching and Learning of Business Education at All Levels}

ICT facilities should be incorporated in the teaching and learning of business education courses at all levels from pre basic/basic to post basic education levels. This could enhance adequate mastery and utilization of ICT facilities.

\section{Conclusion}

For business education to maximally attain its goals in this period of rapid technological changes and development, effort should be made by the business educators to effectively use the ICT facilities in the teaching and learning of business education. This could be enhanced when the suggested strategies are implemented and obstacles stated above reduced or eradicated, so as enhance the production of competitive graduates. 


\section{References}

Akinola, C. I. (2006). Business education and skills development: Entrepreneurship climate must change in Nigeria. Ibadan: Lineage publishing House.

Ali, G., Haolader, F. A., \& Muhammad, K. (2013). The role of ICT to make teaching-learning effective in higher institutions of learning in Uganda. International Journal of Innovative Research in Science, Engineering and Technology, 2(8), 61-73.

Anderson, J. (1997). Integrating ICT and other technologies in teacher education: Trends, issues and guiding principles. Retrieved from https://www.Infotech.Trends

Anunobi, C. V., \& Edoka, B. E. (2010). Use of ICT facilities for serials functions in Southern Nigeria federal university libraries. Library Philosophy and Practice (e-Journal Paper), 355. Retrieved from http://digitalcommons.unl.edu/libphilprac/355

Atepor, L. (2018). Business education in the e-world: Issues, trends, challenges and strategies in Africa. Association of Business Educators of Nigeria Conference Proceedings, 5(1), 1-11.

Egoeze, F., Ibrahim-Akman, S. M., \& Colomo-Palacios, R. (2014). An evaluation of ICT infrastructure and application in Nigeria universities. Acta Polytechnica Hungarica, 11(9), 115-129.

Gana, M. A., \& Abdulrahman, A. (2017). Entrepreneurial skills training needs in business education for internally displaced persons (IDPs) in Borno State for sustainable development. Association of Business Educators of Nigeria Conference Proceedings, 4(1), 468-478.

Mikre, F. (2011). Roles of information communication technology in education. Retrieved from https://www.ajol.info/index.php/ejesc/article/viewFile/73521/62437

Minishi-Majanja, M. (2007). Integration of ICTs in library and information science education in sub-Saharan Africa. Paper presented at The World Library and Information Congress: 73rd IFLA General Conference and Council. Retrieved from http://www.ifla.org/IV/ifla73/index.htm

Moseley, D., Higgins, S., Bramald, R., Hardman, F., Miller, J., \& Mroz, M. (1999). Ways forward with ICT: Effective pedagogy using information and communication technology for literacy and numeracy in primary schools. Newcastle: University of Newcastle.

Obidile, I. J. (2013). Perceived accounting teachers' role for integrating ICT facilities in the teaching of accounting. Journal of Vocational and Adult Education, 8(1), 62-68.

Okoro, C. O., \& Ekpo, E. E. (2016). Effects of information and communication technology (ICT) application on academic achievement of students in Christian religious studies in Cross River State. International Journal of Interdisciplinary Research Method, 3(2), 14-24.

Okwuanaso, S. I., \& Nwazor, J. C. (2000). Instructional strategies in business education. Awka: Ikenga.

Omariba, A. (2012). Teachers' preparedness in integrating information communication technology in training teachers in public primary teachers' training college in central region Kenya (Doctoral thesis, Department of Educational Technology, School of Education, Kenyatta University).

Philip, A., Oluwagbemi, O., \& Oluwaranti, A. (2010). An evaluation of the impact of information and communication technologies diffusion in Nigeria's Higher Educational Institutions. Journal of Information Technology Impact, 10(1), 25-34.

Richmond, R. (2002). Integration of technology in the classroom: An instructional perspective. Retrieved from http://www.ssta.sk.ca/research/technology/97- 02.htm

Rumanyika, J. D., \& Galan, R. M. (2015). Challenges for teaching and learning information and communication technology courses in higher learning institutions. Journal of Information and Knowledge Management, 5(2), 1-12.

Sharma, R. (2003). Barriers in using technology for education in developing countries. Computers \& Education, 41(1), 49-63.

United Nations Educational Scientific and Cultural Organization (UNESCO). (2002a). Information and communication technologies in teacher education: A planning guide. Paris: Division of Higher Education.

Yuen, A., Law, N., \& Wong, K. (2003). ICT implementation and school leadership case studies of ICT integration in teaching and learning. Journal of Educational Administration, 41(2), 158-170.

Yusuf, M. O. (2005). Information and communication education: Analyzing the Nigerian national policy for information technology. International Education Journal, 6(3), 316-321. 